\title{
鼻粘膜自律神経受容体の治療による変化
}

\author{
石 塚 洋一
}

\section{Changes in Autonomic Nerve Receptors in the Nasal Mucosa in Patients with Allergic Rhinitis after Treatment}

\author{
Yoichi Ishizuka \\ (Teikyo University School of Medicine, Mizonokuchi Hospital)
}

\begin{abstract}
Autonomic nerve receptors and histamine $\mathrm{H}_{1}$ receptors in the mucosa of the inferior nasal concha were determined by receptor binding assay in patients with allergic rhinitis, those with allergic rhinitis treated with an NSP nebulizer (NSP group), and controls with chronic sinusitis. The number of acethylcholine receptors was significantly higher in the patients with allergic rhinitis than in the control group and significantly lower in the NSP group than in the patients with allergic rhinitis. The numbers of $\alpha_{1}$ receptors and $\beta$ receptors in the patients with allergic rhinitis were significantly lower than in the control group but similar to those in the NSP group. The number of histamine $\mathrm{H}_{1}$ receptors did not differ among the 3 groups.
\end{abstract}

Key words: allergic rhinitis, autonomic nerve receptor, histamine $\mathrm{H}_{1}$ receptor, receptor binding assay

はじめに

鼻アレルギーの発症には自律神経機能の異常 も梁く関連している. 近年，乙うした自律神経 状態を知るために組織の受容体を分子レベルで 解析することが行われ，自律神経受容体の定量 ができるようになった。これまでの研究による と鼻アレルギーではムスカリン作動性アセチル コリン受容体（以下アセチルコリン受容体）数 は増加し， $\alpha_{1}, \beta$ アドレナージック受容体（以 下 $\alpha_{1}, \beta$ 受容体）数は減少していると言われて いる11.

さらに動物実験からは，卵白アルブミン感作 実験的鼻アレルギーモルモットの鼻粘膜アセチ ルコリン受容体の増加は, 抗アレルギー薬の投
与により抑制されたと報告されている22.

そとで今回, 鼻アレルギー患者の自律神経受 容体の治療による変化について検討したので報 告する.

\section{対象と方法}

対象は HD 鼻アレルギー患者 7 名（男子 4 名，女子 3 名，19〜 40 歳までで平均年齢 27.1 歳)，ノイロトロピン®（以下 NSP と略す）ネ ビュライザー治療後の HD 鼻アレルギー患者 8 名（男子 6 名, 女子 2 名, 19〜 40歳までで平 均年齢28.5歳）である。なお NSP ネビュライ ザーは NSP 特号注射液 1 アンプル $3 \mathrm{ml}$ を通 常のジェット型ネビュライザーにて 3 分間, 週 に $2 \sim 3$ 回， 4 週間投与した. NSP ネビュラ 
イザー療法を施行した 8 名は全例が有効以上の 症例である．対照群として慢性副鼻腔炎患者 13 名（男子 10 名，女子 3 名，22 45歳までで平均 年齢31. 8歳) である. 全症例とも手術時に採取 した下鼻甲介粘膜より受容体数の測定を行った。

測定方法は Ishibe ら3)の方法に準じた receptor binding assay 法を用いてアセチルコリン 受容体, $\alpha_{1}$ 受容体, $\beta$ 受容体, ヒスタミン $\mathrm{H}_{1}$ 受容体について検討した。

1) 粗 receptor 膜の作製法

ヒト鼻粘膜を Ishibe ら ${ }^{3)}$ の方法を改変し図 1 に示す手順によりレセプター膜を調製した。す なわち鼻粘膜を氷冷 $50 \mathrm{mM}$ Tris- $\mathrm{HCl}$ buffer （pH 7.4）で洗浄して血液成分を除去し湿重量 を秤量した。秤量後, 10 容量の水冷 $50 \mathrm{mM}$ Tris- $\mathrm{HCl}$ buffer (pH 7.4) を加え, polytron （キネ・マチカ社製 PT10/35）を用いて homogenize し，ナイロンメッシュで粗大成分を除 去した後, 濾液を $50000 \times \mathrm{g}, 4^{\circ} \mathrm{C}$ で20分間遠心 分離し，乙の操作を 3 回繰り返した。最終沈椬 を incubation buffer (50 mM Tris- $\mathrm{HCl}$ buffer, $\mathrm{NaCl} 120 \mathrm{mM}, \quad \mathrm{KCl} 5 \mathrm{mM}, \mathrm{CaCl}_{2} 2 \mathrm{mM}$, $\mathrm{MgCl}_{2} 1 \mathrm{mM}, \mathrm{pH}$ 7.4) にて懸濁化させ，乙れ をレセプター膜とした。

2 ) receptor binding assay (図 2)

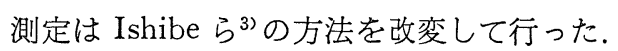
radioligand はアセチルコリン受容体，ヒスタ

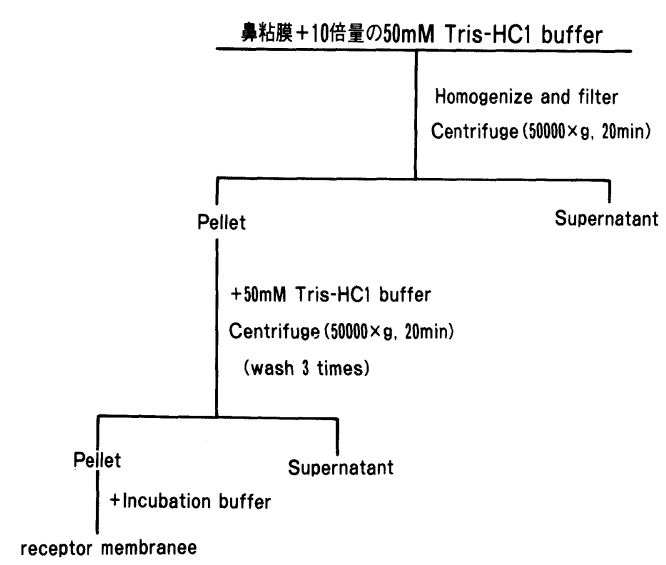

図 1 粗 receptor 膜の作製法
ミン $\mathrm{H}_{1}$ 受容体, $\alpha_{1}$ 受容体および $\beta$ 受容体の測 定にはそれぞれ ${ }^{3} \mathrm{H}$-QNB, ${ }^{3} \mathrm{H}$-pyrilamine, ${ }^{3} \mathrm{H}$ prazosin および ${ }^{3} \mathrm{H}$-DHA を使用した。

アセチルコリン受容体の測定は H-QNB $(0.25 \sim 4.0 \mathrm{nM}) 100 \mu \mathrm{l}$ と鼻粘膜膜標本 (protein 量 $350 \sim 600 \mu \mathrm{l}) 150 \mu \mathrm{l}$ とを incubation buffer の 中で $25^{\circ} \mathrm{C}, 30$ 分間 incubation した。 次いで Whatman GF/F glassfiber filter を用い ${ }^{3} \mathrm{H}$ $\mathrm{QNB}$ 結合型と遊離型を分離し，3 $\mathrm{ml}$ の水冷 Tris- $\mathrm{HCl}$ buffer で 3 回洗浄後, filter をカウン ティング・バイアルに入れ, $60^{\circ} \mathrm{C}$ で $6 \sim 12$ 時間 乾燥した。冷却後, トルエンベースシンチレー ターである Scintisol AL-1 (同仁化学)を $5 \mathrm{ml}$ 加え, radioactivity を液体シンチレーションカ ウンター (Packard instrument Co. Inc. TRICARB 4640) で測定した。非特異的結合量は $2 \times 10^{-6} \mathrm{M}$ atropine 存在下の結合量より求め, total 結合量との差を特異的結合量とした。 七 スタミン $\mathrm{H}_{1}$ 受容体, $\alpha_{1}$ 受容体および $\beta$ 受容 体の測定は incubation 条件をそれぞれ $25^{\circ} \mathrm{C}$, 30 分間， $25^{\circ} \mathrm{C} ， 40$ 分間および $37^{\circ} \mathrm{C}, 10$ 分間で行 い，非特異的結合量はそれぞれ $2 \times 10^{-6} \mathrm{M}$ の triprolidine, $10^{-5} \mathrm{M} の$ phentolamine および $10^{-6} \mathrm{M} の$ propranolol の存在下で求めた。 ま た他の操作はアセチルコリン受容体の測定と同 様にして行った.

蛋白量は Lowry ら4) の方法で定量し,

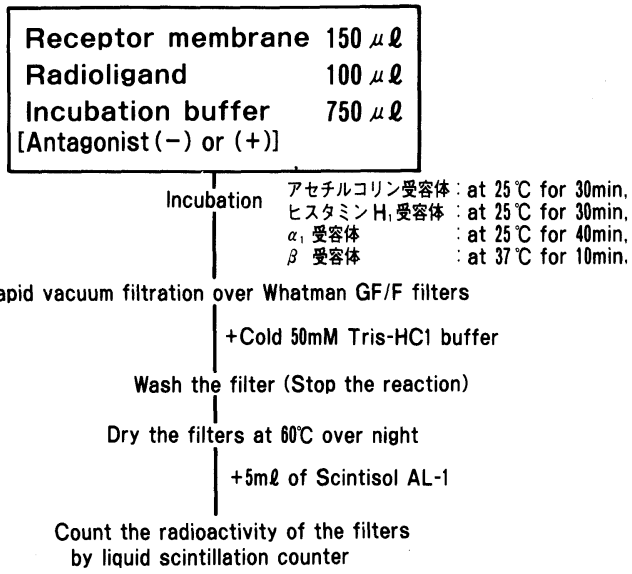

図 2 receptor binding assay 
Scatchard plots ${ }^{5)}$ により maximam specific binding $(\mathrm{Bmax})$ と親和性 $(\mathrm{KD}$ 值)を算出した. またすべての実験は duplicate で行った.

\section{結果}

アセチルコリン受容体は, 慢性副鼻腔炎の対 照群が平均 $161.9 \pm 4.9 \mathrm{fmol} / \mathrm{mg}$ protein に比 較し鼻アレルギー群の平均 258.8 土88.6 亿有意 に高值を示していた $(\mathrm{P}<0.05)$.

鼻アレルギー群と NSP 治療群を比較してみ

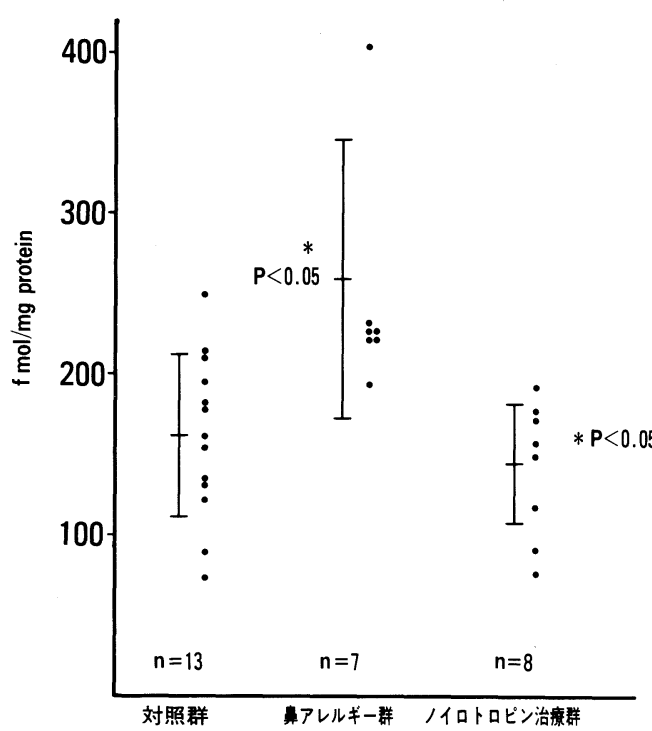

図3 鼻アレルギー治療によるアセチルコリン受 容体の変化

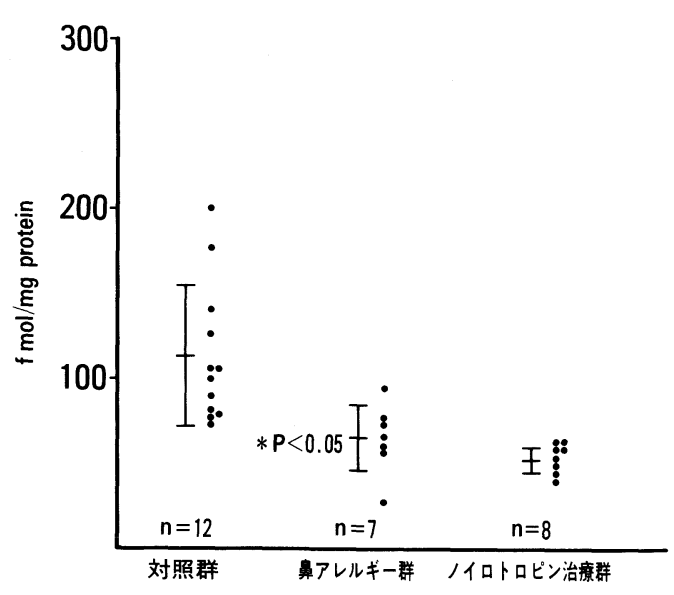

図 4 鼻アレルギー治療による $\alpha_{1}$ 受容体の変化
ると, NSP 治療群は平均 $145.9 \pm 37.1 \mathrm{fmol} / \mathrm{mg}$ protein と有意に低下 $(\mathrm{P}<0.05)$ している（困 3 ).

$\alpha_{1}$ 受容体は，対照群が平均 $115.5 \pm 42.4$ $\mathrm{fmol} / \mathrm{mg}$ protein に比較し鼻アレルギー群の平 均は $67.3 \pm 19.5 \mathrm{fmol} / \mathrm{mg}$ protein と有意に低 值を示している $(\mathrm{P}<0.05)$.

鼻アレルギ一群と NSP 治療群を比較してみ ると, NSP 治療群は平均 $55.6 \pm 7.2 \mathrm{fmol} / \mathrm{mg}$ protein と有意な差は認めない（図 4).

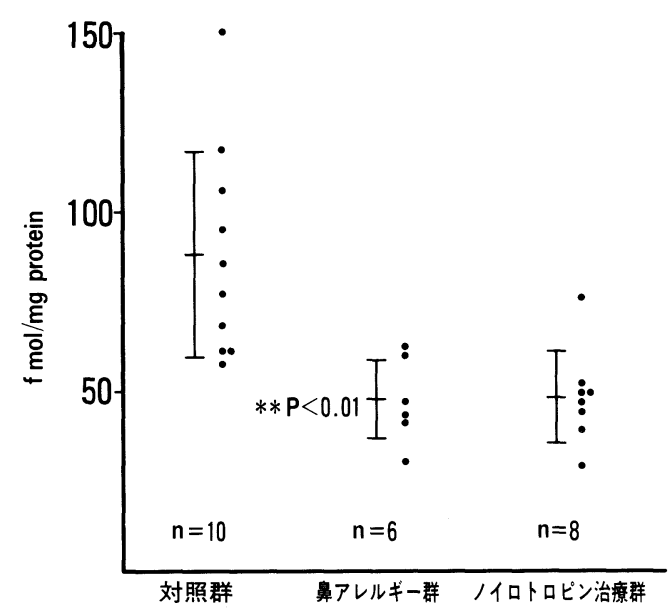

図 5 鼻アレルギー治療による $\beta$ 受容体の変化

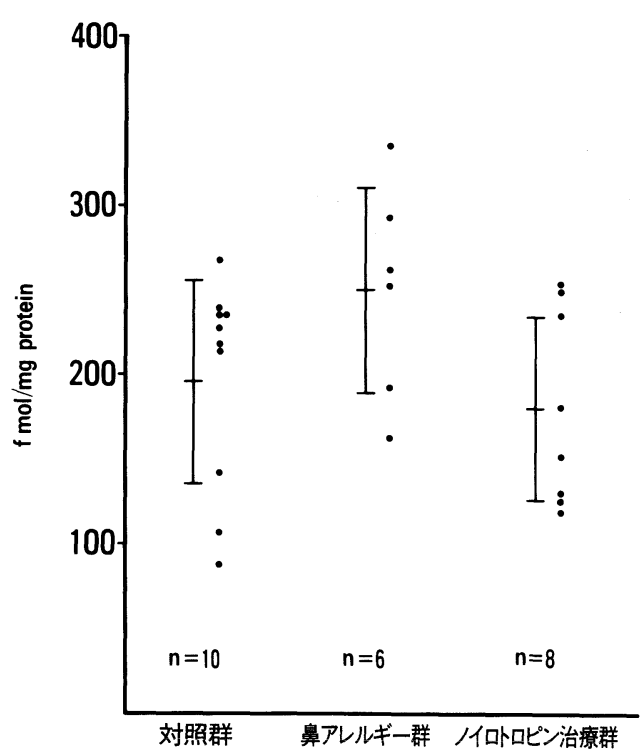

図 6 鼻アレルギー治療によるヒスタミン $\mathrm{H}_{1}$ 受 容体の変化 
$\beta$ 受容体は対照群が平均 $89.2 \pm 29.0 \mathrm{fmol} /$ $\mathrm{mg}$ protein に比較し鼻アレルギー群の平均 $48.2 \pm 11.1 \mathrm{fmol} / \mathrm{mg}$ protein と有意に低值を示 している.

鼻アレルギー群と NSP 治療群を比較してみ ると, NSP 治療群は平均 $51.7 \pm 15.3 \mathrm{fmol} / \mathrm{mg}$ protein と差は認めない（図 5 ).

ヒスタミン $\mathrm{H}_{1}$ 受容体は, 対照群 196.8土 $59.2 \mathrm{fmol} / \mathrm{mg}$ protein, 鼻アレルギー群 $249.8 \pm$ $58.9 \mathrm{fmol} / \mathrm{mg}$ protein, NSP 治療群 179.3 土 $54.7 \mathrm{fmol} / \mathrm{mg}$ protein と各群に有意な差は認め ない(図6).

アセチルコリン受容体, $\alpha_{1} \cdot \beta$ 受容体, ヒス タミン $\mathrm{H}_{1}$ 受容体の $\mathrm{KD}$ 值は対照群, 鼻アレ ルギー群, NSP 治療群の間に有意な差は認めな かった.

\section{考察}

NSP は，ワクシニアウィルスを接種した家 鬼の炎症性皮膚組織加分離抽出された多糖体 である. 古くからアレルギー性疾患の治療に注 射剂として用いられてきた。近年, 鼻アレルギ 一にも用いられその有效性が報告されている ${ }^{6)}$. NSP の薬理作用として, mast cell の脱顆粒や histamine 遊離を抑制し，アレルギー反応を起 こしにくくさせるという作用が動物実験からも 明らかにされている778)。 またNSP の作用部位 として中枢の他に自律神経末梢のアセチルコリ ン受容体に保護作用をむつといわれている ${ }^{9}$.

鼻アレルギーの非特異的療法の一つとして, 注射により投与されていた NSP は，作用機序 加ら局所療法による効果も期待できるものと考 えられる．乙れまでにわれわれはNSP を鼻ア レルギーに対しネビュライザーにて局所投与し， 有効以上 $69.6 \%$ の有効率が得られたととを報告 した ${ }^{10)}$.

このように臨床的にも，鼻アレルギーに対し NSP をネビュライザーにて使用し治療効果を 認めたてとから, NSP のネビュライザ一療法に おける作用機序を解明する目的で，自律神経受 容体とヒスタミン $\mathrm{H}_{1}$ 受容体を測定する基礎的
検討を行った.

その結果，鼻アレルギー患者のアセチルコリ ン受容体は対照群と比較し有意に高く, NSP 治 療群は鼻アレルギ一群に比較し有意に低かった。 これは NSP ネビュライザ一療法がアセチルコ リン受容体の増加を改善させたものと思われる. しかし $\alpha_{1}$ 受容体, $\beta$ 受容体は対照群に比較し, 鼻アレルギー群で有意に低下していたが，NSP 治療群屯同様に低下していた。

今回の研究において，アセチルコリン受容体 は有意に上昇し， $\alpha_{1} ・ \beta$ 受容体が鼻アレルギー 群で有意に低下していた点はてれまでの報告1 に一致している。ささに NSP 治療群のアセチ ルコリン受容体は鼻アレルギー群より有意に低 下しており，抗アレルギー薬を用いて検討した 寺田ら ${ }^{2)}$ の動物実験の結果と同じ結果であっ た。またヒスタミン $\mathrm{H}_{1}$ 受容体は各群に有意な 差はみられなかった。

自律神経受容体の変動に関しては, 今野ら ${ }^{11}$ はアセチルコリン受容体の变化は鼻腺分泌元進, 鼻粘膜血管拡張, 好塩基性細胞の脱顆粒促進を おこし， $\alpha_{1}$ 受容体の変化は鼻粘膜血管拡張を， $\beta$ 受容体の変化は好塩基性細胞脱顆粒を促進 し，いずれも鼻過敏症状増悪の原因となると述 べている.

自律神経受容体は鼻腺, 鼻粘膜血管, 好塩基 性細胞などの細胞表面に分布している.

鼻アレルギーの鼻粘膜におけるアセチルコリ ン受容体の数の増加は, 卵白アルブミン感作に よって作製した $\operatorname{IgE}$ および $\gamma_{1}$ 抗体関与の明ら かな鼻アレルギーモルモット鼻粘膜に㧊いて容 易に再現できることから，乙のアセチルコリン 受容体の数の増加は感作と過敏反応反復の結果 と考えられている(2).

これらの点と, 鼻アレルギーに NSP ネビュ ライザー療法が有効であったととを考え合わせ ると, NSP ネビュライザー療法は，自律神経系 特にアセチルコリン受容体に作用し鼻過敏症状 を軽減させたものと推察される。乙れは NSP ネビュライザー療法が鼻アレルギーの中でもく 


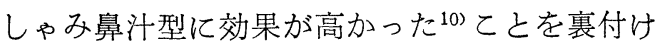
る結果となった。

\section{まとめ}

鼻アレルギー群, NSP ネビュライザー治療を 行った鼻アレルギー群, 対照群として慢性副鼻 腔炎群それぞれの手術時に採取した下鼻甲介粘 膜より, 自律神経受容体とヒスタミン受容体に ついて検討した.

1) アセチルコリン受容体は, 鼻アレルギー 群では対照群と比較し有意に多く, NSP 治療群 では鼻アレルギー群と比較し有意に少なかった。

2) $\alpha_{1}$ 受容体, $\beta$ 受容体については, 両者之 あ鼻アレルギー群では対照群と比較し有意に少 なく, NSP 治療群では鼻アレルギー群と比較し 差は認めなかった。

3) ヒスタミン $\mathrm{H}_{1}$ 受容体は, 対照群, 鼻ア レルギー群, NSP 治療群とも有意な差は認めな かった.

以上のととより，アセチルコリン受容体の変 化は鼻腺分泌元進をおこすとされており，NSP ネビュライザー療法が鼻アレルギーの鼻過敏症 状を軽快させたものと思われる。

稿を終るに臨み, 本研究に御協力いただいた日本臓 器生物活性科学研究所任感謝申し上げます.

本論文の要旨は, 第12回日本医用エアロゾル研究会 において報告した。

\section{参考文献}

1）寺田修久, 今野昭義, 岡本美孝: ヒト鼻アレルギ 一および感作モルモットにおける鼻粘膜自律神経 受容体について. 日耳鼻 $88 ： 1153 \sim 1161 ， 1985$.

2 ) 寺田修久, 今野昭義, 安藤英樹, 他 : 卵白アルブ ミン感作鼻アレルギーモルモットにおける鼻粘膜 ムスカリニック受容体の変化と薬物療法による影
響. 日耳鼻 $91 ： 847 \sim 855 ， 1988$.

3 ) Ishibe $T$, Yamashita $T$, Kumazawa $T$, et al : Adrenergic and cholinergic receptors in human nasal mucosa in cases of nasal allergy. Arch Otorhinolaryngol $288: 167 \sim 173,1983$.

4) Lowry $\mathrm{OH}$, Rosebrough NJ, Fall AL, et al : Protein measurement with the Folin phenol reagent. J Biol Chem 193 : 265 275, 1951.

5 ) Scatchard G: The attractions of proteins for small molecules and ions. Ann N Y Aca Sci $51: 660 \sim 672,1949$.

6) 奥田 稔, 打越 進, 海野徳二, 他: 鼻アレルギ 一に対するノイロトロピンの治療効果の検討. 耳 鼻臨床 $72: 779 \sim 799,1979$.

7 ) 柳原行義, 信太隆夫 : Neurotropin の免疫薬理学 的作用（第 3 報）一抗アレルギー作用についての 検討一. 日薬理誌 $78: 589 \sim 597,1981$.

8 ）江田昭英, 永井博式, 栗本芳行, 他：ノイロトロ ピン (NSP) のアレルギー反応に及ぼす影響. 日 薬理誌 $78: 319 \sim 334,1981$.

9 ）泰多恵子, 浪松昭夫, 伊藤栄次, 他：小腸ならび に精管の denervation-supersensitivity を用いた Neurotropin の作用解析. 脳研究会会誌 8:52 53, 1982.

10）石塚洋一, 木村元俊, 大西由紀, 他: 鼻アレルギ 一に対するノイロトロピンネビュライザー療法の 効果一くしゃみ型を中心に一. 耳展 $30: 103$ 106, 1987.

11）今野昭義, 寺田修久, 伊藤永子：鼻アレルギーと 自律神経. アレルギー診療 5：133〜145, 1986.

12）今野昭義, 寺田修久: 鼻アレルギーと鼻粘膜自律 神経受容体. 耳鼻 $31: 1263 \sim 1280,1971$.

$\left(\begin{array}{l}\text { 原稿採択 : 昭和 } 63 \text { 年 } 12 \text { 月 } 12 \text { 日 } \\ \text { 別刷請求先 : 石塚洋一 } \\ \text { 干 } 213 \text { 川崎市高津区溝口 } 74 \\ \text { 帝京大学殹学部耳鼻咽喉科学教室溝口病院 }\end{array}\right)$

